\title{
Values Education in Architectural Education: An Example from Huizhou University
}

\author{
Wei Li*, Zhe Chen, Lanlan Lai \\ School of Architecture and Civil Engineering, Huizhou University, Huizhou, China \\ Email: *doublelai@126.com
}

How to cite this paper: Li, W., Chen, Z., \& Lai, L. L. (2021). Values Education in Architectural Education: An Example from Huizhou University. Creative Education, 12, 1186-1191.

https://doi.org/10.4236/ce.2021.125088

Received: April 27, 2021

Accepted: May 28, 2021

Published: May 31, 2021

Copyright (c) 2021 by author(s) and Scientific Research Publishing Inc. This work is licensed under the Creative Commons Attribution International License (CC BY 4.0).

http://creativecommons.org/licenses/by/4.0/

\begin{abstract}
The new understanding of daxue zhidao (大学之道) in the new Era refers to the ethos of university-illuminating values, renovating students and pursing excellence. This paper exemplifies the Bauhaus Style Construction Competition to show how the PCDIO procedure works.
\end{abstract}

\section{Keywords}

Illustrating Values, Renovating Students, Pursuing Excellence, Architecture Education, PCDIO

\section{Introduction}

The so-called daxue zhi dao (大学之道) in the Confucianism refers to the great way of learning to become a great or noble person, however I use the term to mean the values of modern university. Inspired by daxue zhidao, its ethos of university are to illuminating values (明明德), renovating students (亲民; 新民) and pursuing excellence (止于至善) (Zhu, 1983; my translation), which becomes a rich source of inspiration and education philosophy for modern university. In other words, it can be interpreted today as suggesting the ethos of a university are to cultivate and manifest the moral values of the society, to enhance their creativity and innovative spirit and pursue excellence as its ultimate end. This can be taken as the basic ethos normative and ideal for university education. Thus, it also manifests that the modern university should strive to enhance values education. Values education is defined by (Aspin, 2000) "as an introduction into values and morality, to give young people knowledge of this domain about relating to other young people, together with the ability to apply the values and rules intelligently, and to have the settled disposition to do so". Taylor points out that "values education is an umbrella term including moral education, civic 
education, and citizenship education etc. Furthermore, Taylor (1994: p. 3) added that values education encourages reflections on choices, exploration of opportunities and commitment to responsibilities for both the individual and society, to develop values preferences and an orientation to guide attitudes and behaviour". Socialism values education has been part of the school curriculum since the foundation of the new China, however with the development of the new China and socialism, guided by Xi Jinping Thought on Socialism with Chinese Characteristics for a New Era, a philosophical bases for higher education. Thus, values education and curriculum design in higher education have around a heated discussion. This paper attempts to show how values education is embodied in the curriculum design with the new teaching method-PCDIO.

\section{Illustrating Values}

Illustrating values is commonly underpinned by an ideology of Socialism with Chinese Characteristics for a New Era. All students take the compulsory subject on values education since kindergarten. Values education for the young especially the college students is a primary concern in higher education, which aims to cultivate people to serve for our country. The overarching aim of values education is to cultivate a person of a good personality, one who is caring and acts responsibly towards the self, family, community, nation and the world. Values education in higher education is far more reaching than that in the pre-university period. Values embodied in the architectural education including our society shared common values, citizenship education, civics and moral education as well as engineering ethics, such as respect, responsibility, care, integrity, harmony and perseverance. Values education for college students underlines their social roles and obligations to others are more apparent, profound and lasting, which highlights the importance of values education hidden in subject education. Specifically, this paper discusses values education in undergraduate architecture programme. In other words, it explores how the values education permeates in the architectural education and vice versa.

Architecture, as the combination of art, engineering and science, the practice of architecture is employed to fulfill both practical and expressive requirements, and thus it serves both utilitarian and aesthetic ends. Although these two ends may be distinguished, they cannot be separated, and the relative weight given to each can vary widely. Because every society-settled or nomadic-has a spatial relationship to the natural world and to other societies, the structures they produce reveal much about their environment (including climate and weather), history, ceremonies, and artistic sensibility, as well as many aspects of daily life, which is well suitable for such an attempt with an innovative teaching procedure.

\section{Renovating Students}

Renovating students with innovative teaching methods to realize students' po- 
tential. Teaching methods renovation is an important link to bridge the values education and the curriculum design. Under the guiding philosophy of "student-oriented", a combination PBL (Problem/Project-based learning) and CDIO (conceive-design-implement-operate) are applied into our architectural education reform. The late 1960s and early 1970s saw a rapid development and expansion in educational systems. The PBL model was first invented and implanted especially in health education at McMaster University (1968) and Maastricht (1972). Gradually, it was practiced in a wide range of subject such as engineering, science, social science and humanities (Illeris 1976; Neville \& Norman 2007; Kolmos \& de Graaff 2013). This pedagogy was developed on the educational philosophy- "student-oriented" and added to a theory of learning with cognitive, emotional, and social dimensions. The CDIO refers to the engineering practice: conceiving, designing, implementing, operating products, process and systems. CDIO was first implemented at Massachusetts Institute of Technology (MIT) in the late 1990s as a response to conventional engineering education, due to the fact that in many institutions engineering practice was replaced by engineering science as the dominant culture (c.f: Kristina \& Anette, 2014). The CDIO method is beneficial for engineering practice, focusing on outcome-based accreditation standards and a wider set of skills, which aims to strengthen the professional skills and engineering ethics. Thus, based on the combination of $\mathrm{PBL}$ and CDIO, the PCDIO is initiated to the architectural education reform.

Taking the Construction Competition “In Memory of Haus Bauhaus's 100 Birthday Anniversary" as an example to illustrate the new teaching procedure. The project is to create a $3 \mathrm{~m} \times 3 \mathrm{~m} \times 3 \mathrm{~m}$ space with pp plate sheet under the Bauhaus design principles: use of Minimalism, Simplicity and Effectiveness, which is used as a recreation or learning space meeting the requirements of windproof, waterproof and durability. Besides, the Bauhaus design emphasis on new material, new technology and new techniques, which confirms our education philosophy. Figure 1 shows how the teaching works with the new procedure.

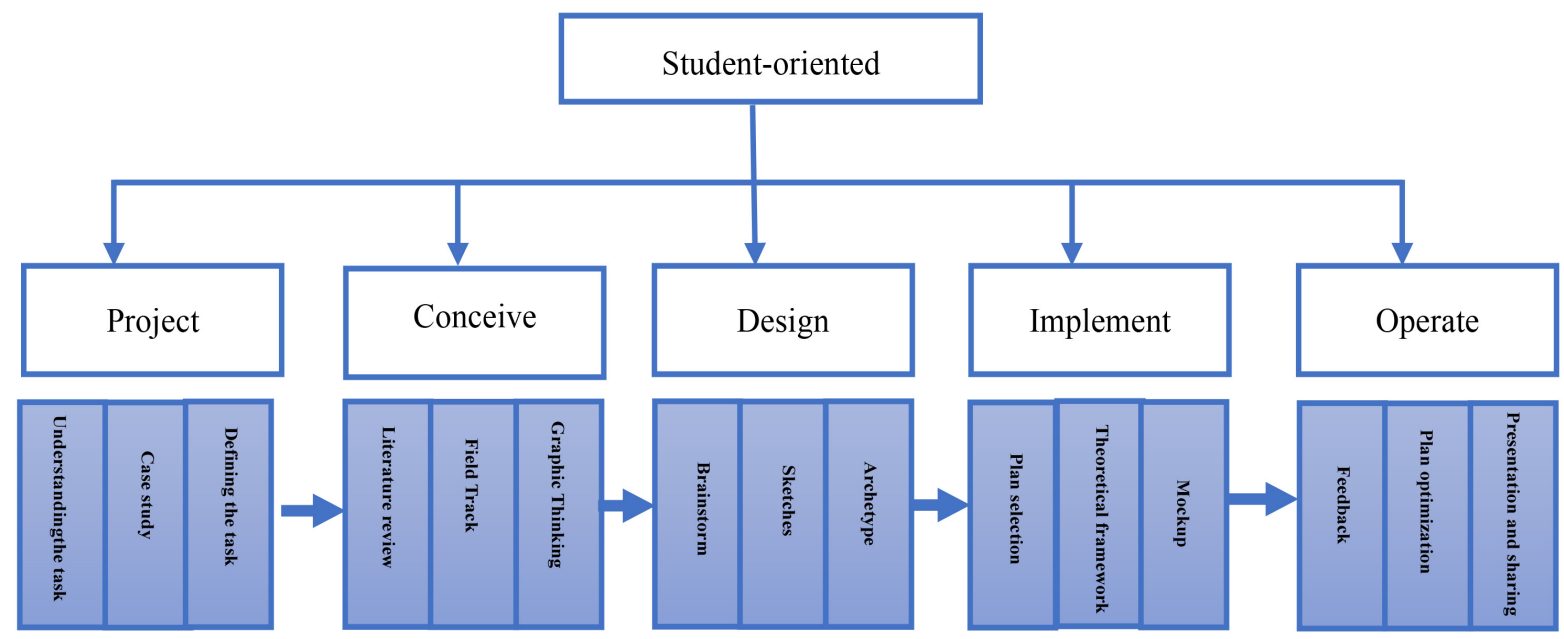

Figure 1. PCDIO teaching procedure. 
The teaching begins with a project, including understanding and defining the task together with case study. However, our values education permeates the whole process and the project from beginning to the end. Values and ethics concerned with architecture, mankind, society, community are embodied in the curriculum design and teaching contents. Then, it moves to the conceiving procedure, which is more a conceptual process or preparation process including literature review, field track and graphic thinking. As for the designing process, brainstorm, sketches and archetype are used based on the conceptual process. Having finished the previous processes, plan selection, theoretical framework and mockup are implemented to preview how a design could look or function in the real world. When it moves to the final process, that's to say, the product is being operated in the real world. Feedback, plan optimization and presentation \& sharing are applied to perfect the final product. This teaching procedure is student-oriented and outcome-based beginning with an actual project and ending with a real-world product, which can boost students' creativity and productivity.

\section{Pursuing Excellence}

Pursuing excellence has a long tradition in China and has been encouraged in the New Era. Gongjiang jingshen (工匠精神) literally means the spirit of craftsmanship, urging young people to carry forward craftsmanship and strive for excellence to serve the country. In China, the word for "craftsman" was created during the Spring and Autumn Period (770-476 BC) when skillful artisans began to engage in individual handicraft production as a result of division of labor. At first the word mainly referred to carpenters. Its use expanded to cover all handicraftsmen during the Eastern Han Dynasty (25-220). The ancient craftsmen were known for their inventive talent, superb skills, and dedication to their trade. On top of these traits contemporary craft workers are also known for their professional ethics, pursuit of quality, good teamwork, and ability to innovate. While carrying on the spirit of ancient craftsmen, today's workers also learn from foreign sources in their endeavors to make China a strong modern manufacturer and realize the Chinese Dream. As for the architectural education, a strong sense of craftmanship striving for excellence is. (Halstead \& Xiao, 2010) contend that besides the basic skills and knowledge, the positive sides of values enculturation such as the skills of questioning, framing and creating new solutions, the attitude, mentality that came from the basic courses of architecture. During the whole competition, students are supposed to undergo twelve steps in the four stages (Figure 1). Once students register for the project, they have to present their plan and get feedback, then moves to the next stage-mockup presentation and plan optimization, finally the work exhibition. Notably, it took the whole team 36 hours without day and night to finish their final work (Figure 2). After participating the competition, students cultivated a sense of pursuing excellence, pursing aesthetics, pursuing truth. 

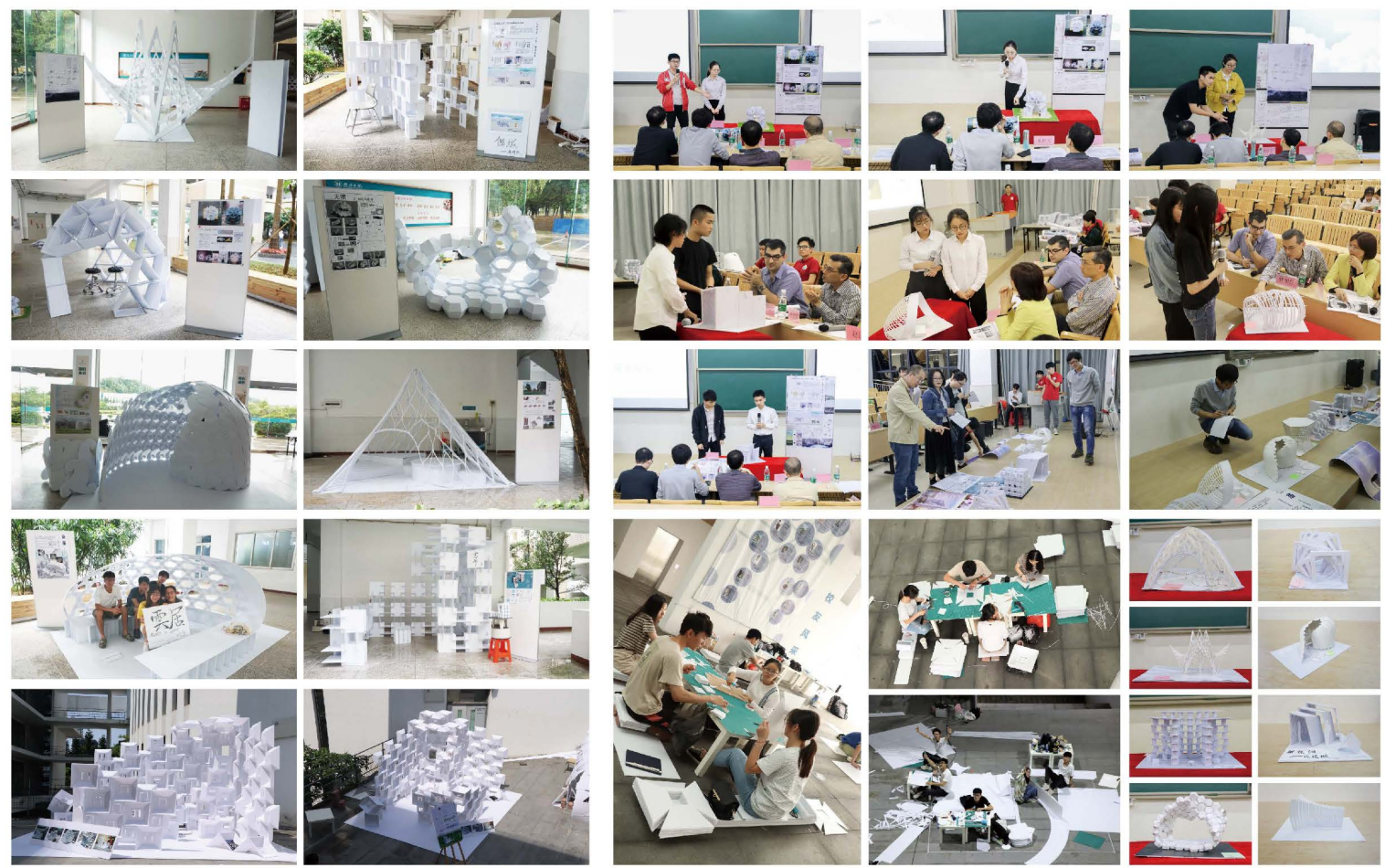

Figure 2. The Bauhaus style construction competition in 2019.

\section{Conclusion}

This attempt provides a useful case study on the values education embodied in subject teaching in China with PCDIO teaching procedure, which yields fruitful achievements. Students have higher level of confidence, stronger sense of pursuing excellence. Illustrating values is of first priority and decides the education aim-meeting the requirements of the socialism with the Chinese Characteristics for the New Era. Renovating students with new teaching procedure is the realization of education aim and purpose. Pursuing excellence is the ultimate end for education.

\section{Funding}

The author would like to express heartfelt thanks to Guangdong Higher Education Teaching Reform Project and Guangdong Teaching Quality and Teaching Reform Project under Construction for providing financial support.

\section{Conflicts of Interest}

The authors declare no conflicts of interest regarding the publication of this paper.

\section{References}

Aspin, D. (2000). A Clarification of Some Key Terms in Values Discussions. In M. Leicester, C. Modgil, \& S. Modgil (Eds.), Moral Education and Pluralism: Education, Culture and Values (pp. 171-180). London: Farmer Press. 
Halstead, M., \& Xiao, J. (2010). Values Education and the Hidden Curriculum. In T. Lovat, R. Toomey, \& N. Clement (Eds.), International Research Handbook on Values Education and Student Wellbeing (pp. 303-317). Dordrecht: Springer. https://doi.org/10.1007/978-90-481-8675-4_19

Illeris, K. (1976). Problemorientering og deltagerstyring: oplæg til en alternative didaktik. Copenhagen: Munksgaard.

Kolmos, A., \& de Graaff, E. (2013). Problem-Based and Project-based Learning in Engineering Education-Merging Models. In A. Johri, \& B. M. Olds (Eds.), Cambridge Handbook of Engineering Education Research (CHEER) (pp. 141-160.). New York: Cambridge University Press.

Kristina, E., \& Anette, K. (2014). PBL and CDIO: Complementary Models for Engineering Education Development. European Journal of Engineering Education, 39, 1-19.

Neville, A. J., \& Norman, G. R. (2007). PBL in the Undergraduate MD Program at McMaster University: Three Iterations in Three Decades. Academic Medicine, 82, 370-374. https://doi.org/10.1097/ACM.0b013e318033385d

Taylor, M. (1994). Overview of Values Education in 26 European Countries. In M. Taylor (Ed.), Values Education in Europe: A Comparative Overview of a Survey of 26 Countries in 1993 (pp. 1-66). Dundee: Scottish Consultative Council on the Curriculum.

Zhu, X. (1983). Collected Commentaries on Chapters and Sentences of the Four Books. Beijing: Zhonghua Shuju. 